\title{
Health needs as a priority of local authorities in Poland based on the example of implementation of health policy cancer programmes
}

\author{
Anna Augustynowicz ${ }^{1}$, Aleksandra I. Czerw ${ }^{1}$, Andrzej Deptała ${ }^{2}$
}

${ }^{1}$ Department of Public Health, Medical University of Warsaw, Warsaw, Poland ${ }^{2}$ Department of Cancer Prevention, Medical University of Warsaw, Warsaw, Poland

Submitted: 10 June 2016

Accepted: 1 August 2016

Arch Med Sci 2018; 14, 6: 1439-1449

DOI: https://doi.org/10.5114/aoms.2016.62283

Copyright $\odot 2016$ Termedia \& Banach

\section{Abstract}

Introduction: In developed countries, malignant tumours are the second most common cause of death after cardiovascular diseases. The estimates made by epidemiologists indicate that the incidence and death rate for malignant tumours all over the world, Poland included, will probably grow in the decades to come, specifically among patients who are over 65 . The aim of the study was to evaluate how local government units address the health needs of citizens on the basis of an analysis of health policy programmes concerning malignant tumours completed in Poland in 2009-2014.

Material and methods: The study was based on desk research. The data included in the annual reports submitted to the Minister of Health concerning completed health policy programmes were used.

Results: The most programmes were completed in the Wielkopolskie and the Mazowieckie voivodeships, whereas the fewest were completed in the Kujawsko-Pomorskie and the Podlaskie voivodeships $\left(\chi^{2}(15)=2121.81\right.$, $p<0.001)$. The most programmes were completed by municipalities, followed by counties and, finally, self-governed voivodeships $(Q(2)=1967.90$, $p<0.061)$. The majority of programmes concerned breast cancer and cervical cancer. There was no increase in the activity of local government units in terms of the number of implemented programmes, and a decreasing size of the population covered by the programmes.

Conclusions: There is a very high degree of differentiation in the involvement of particular voivodeships in fighting cancer regarding the number of implemented health programmes. There are various degrees of involvement of particular types of local government units in the implementation of programmes in the field of cancer. The repeatability of actions undertaken at the local and national level may indicate limited effectiveness of the policy to fight cancer. It is necessary to implement more programmes in the field of oncological diseases and to increase the population covered by these programmes.

Key words: health policy programme, local government unit, malignant tumour.

\section{Introduction}

In developed countries, malignant tumours are the second most common cause of death after cardiovascular diseases [1]. The estimates made by epidemiologists indicate that the incidence and death rate for malignant tumours all over the world, Poland included, will probably

\author{
Corresponding author: \\ Aleksandra I. Czerw MD, PhD \\ Department of Public Health \\ Medical University \\ of Warsaw \\ Zwirki Wigury St \\ 08-456 Warsaw, Poland \\ Phone: +48 501176370 \\ E-mail: ola_czerw@wp.pl
}


grow in the decades to come, specifically among patients who are over $65[2,3]$.

The incidence of malignant tumours in Poland has more than doubled over the last three decades [1]. Since 2003, there have been 120,000 cases of malignant tumours reported every year [4]. In 2009, the National Register of Tumours received information about 138,000 new cases [5], and in 2013, the number reached 156,000 [6]. The standardised incidence rate in 2010 reached a total of 220.8/100,000 [7], while in 2013, it grew to $232.4 / 100,000$ [6]. In 2006, the 5-year prevalence rate in Poland was estimated to be 323,000 , while in 2012 it reached 364,000 [2]. Among the patients diagnosed in 2003-2005, the 5-year survival rate was $37.3 \%$ for men and $53.5 \%$ for women [1]. In 2011-2013, the number of deaths per year exceeded 94,000 [6, 8, 9].

The incidence of malignant tumours in Poland was lower than the EU average by $20 \%$ among men and $10 \%$ among women [10]. The mortality rate among patients with malignant tumours in Poland was higher than the EU average, by around $20 \%$ among men and around 10\% among women [1]. The survival time among patients diagnosed with cancer in Poland was also shorter than the European average, both for men and women. The average 5-year survival rate in the European Union in $2000-2002$ was $47.3 \%$ for men and $55.8 \%$ for women [10].

A document entitled "Strategy for Fighting Cancer in Poland in 2015-2024" points out the main directions of change aimed at the improvement of population incidence and mortality ratios associated with cancer in Poland and the quality of life of patients with cancer [11]. The White Book report, drawn up under the auspices of the Polish Association of Oncologists, presents key actions that should be taken in oncology care in Poland [12]. The documents stress that initiatives at a national and regional level, as well as involvement of a wide range of entities, including the Ministry of Health, the National Health Fund, local government units, non-governmental organisations and scientific societies, are required. At the national level, there was the National Programme for Fighting Cancer implemented in 2005-2015 [13]. The programme is continued as the National Programme for Fighting Cancer in 2016-2024 [2]. An example of regional initiatives is the health policy programmes implemented by local government units.

In light of the above data, an assessment of the implementation of health policy programmes, aimed at preventing and diagnosing malignant tumours in the Polish population, is well founded.

The aim of the study was to evaluate how local government units address the health needs of citizens on the basis of an analysis of health policy programmes concerning malignant tumours completed in Poland in 2009--2014.

\section{Material and methods}

The study was based on desk research. The data included in the annual reports submitted by voivodes to the Minister of Health concerning health policy programmes implemented by local government units were used. The analysis covered all health policy programmes that concerned malignant tumours completed in 2009-2014 - in all, 3,850 programmes.

The analysis covered programmes whose name, objective or description of tasks indicated that they concern a malignant tumour. The programmes were classified into one of the following four group types: preventive programmes, diagnostic programmes, therapeutic programmes or preventive, diagnostic and therapeutic programmes. The programmes were classified into particular groups on the basis of the objective specified by a given local government unit, the type of programme and the description of actions taken under the programme.

The analysis of the number of completed programmes, depending on the voivodeship and year, was based on a $\chi^{2}$ test for one sample. The test allowed for verification whether particular voivodeships implemented the same number of programmes and whether the same number of programmes was completed in the following years.

The analysis of the number of completed programmes, depending on the local government unit, type of the programme and the group of people to whom the programme was addressed, in control of the voivodeship and the year to which the data referred, was conducted on the basis of Cochran's $Q$ test. The said analysis verified the differences between local government units and various programmes conducted in specific voivodeships in particular years.

The differences in terms of the costs of implemented health policy programmes, depending on the type of programme and local government unit that ran the programme, were analysed by means of a two-way analysis of variance. A one-way analysis of variance was applied for an evaluation of differences in the average values of expenditure on the programmes in voivodeships in particular years.

The size of the population covered by a given programme, depending on the year of implementation, the entity running the programme, the type of programme and the overall cost, was analysed on the basis of regression analysis. When analysing the relations that applied to the entity running a programme, municipality was used as a reference (the most common executor of programmes concerning malignant tumours). When 


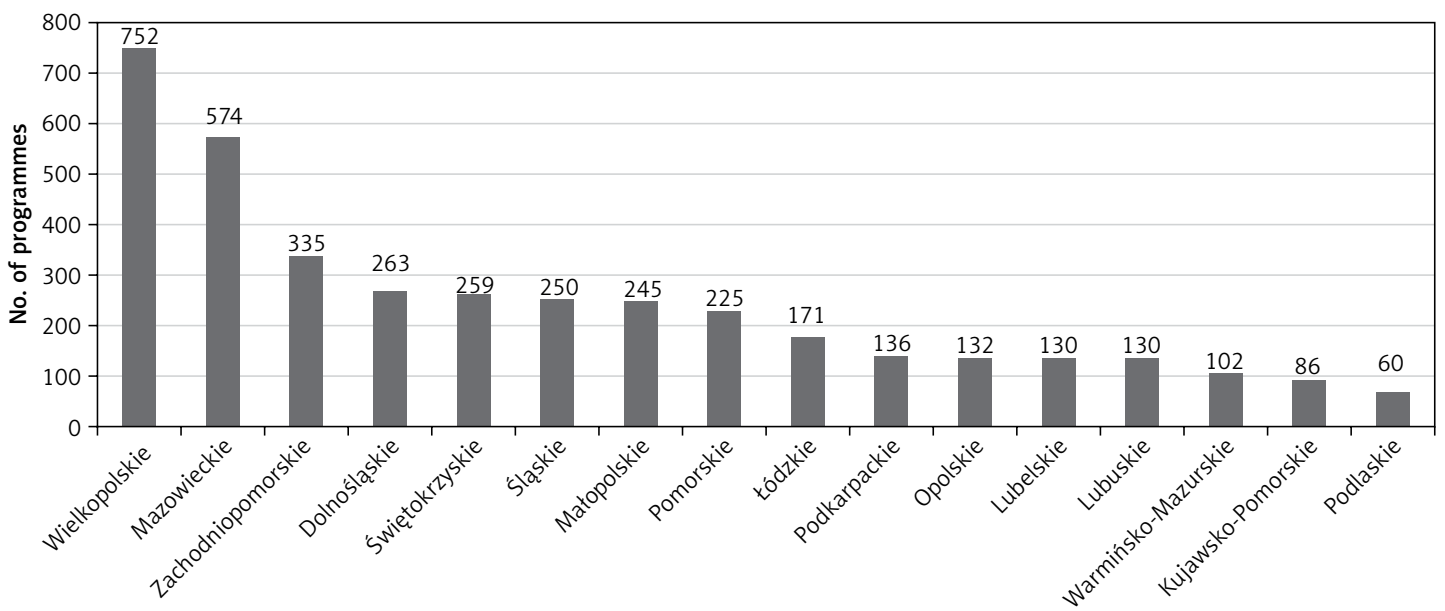

Voivodeship

Figure 1. Frequency distribution - the number of programmes implemented in particular voivodeships in 2009-2014

analysing the relations that applied to the type of programme, diagnostic programmes were used as a reference (the most common programmes concerning malignant tumours).

\section{Results}

Based on the $\chi^{2}$ test for one sample it was found that there were statistically significant differences concerning the number of programmes implemented in particular voivodeships, $\chi^{2}(15)=$ 2121.81, $p<0.001$.

The most programmes were implemented in Wielkopolskie and Mazowieckie voivodeships, while the fewest were implemented in Kujawsko-Pomorskie and Podlaskie voivodeships (Figure 1). On the basis of the $\chi^{2}$ test for one sample it was found that there were statistically significant differences in the number of programmes held in particular years, $\chi^{2}(5)=17.21, p<0.01$.

The most cancer programmes were implemented in 2010, the fewest the year before (Figure 2). The analysis also covered the number of health programmes implemented in particular voivodeships according to the original location of the tumour (Table I).

The most frequent health policy programmes implemented by local government units were programmes for breast cancer and cervical cancer. The most programmes aimed at breast cancer were implemented in Wielkopolskie and Mazowieckie voivodeships, while the fewest were implemented in Kujawsko-Pomorskie and Podlaskie voivodeships. On the basis of Cochran's Q test it was found that there was a statistically significant difference in the number of programmes implemented by particular local government units, $\mathrm{Q}(2)=1967.90, p<0.001$.

The most programmes were implemented by municipalities and towns, fewer programmes were run by counties and county towns, while the fewest programmes were held by voivodeships (Figure 3).

There was a statistically significant increase in the number of programmes implemented by municipalities in the successive years. At the same time there was a decrease in the number of programmes implemented by counties. No statistically significant difference was found in the number of programmes implemented by self-governed voivodeships (Table II).

The analysis also covered the diversity of programmes in terms of the type - preventive programmes, diagnostic programmes, therapeutic programmes or preventive, diagnostic and therapeutic programmes (Figure 4). On the basis of Cochran's $\mathrm{Q}$ test it was found that there are statistically significant differences in the number of programmes implemented by particular local government units, $\mathrm{Q}(3)=5207.62, p<0.001$.

Diagnostic programmes were the most popular, followed by preventive programmes, therapeutic programmes and finally preventive, diagnostic and therapeutic programmes.

It was found that there was a statistically significant increase in the number of preventive programmes implemented in the successive years. The number of diagnostic programmes held in

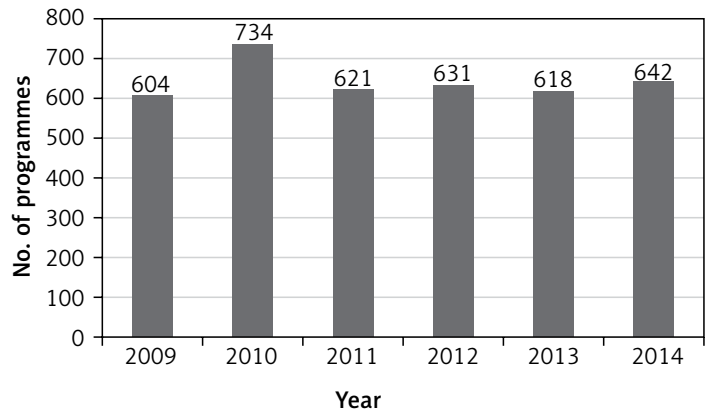

Figure 2. Frequency distribution - the number of programmes implemented in 2009-2014 
Table I. Frequency distribution - programmes implemented in particular years according to the original location of the tumour

\begin{tabular}{|lccccccc|}
\hline Voivodeship & \multicolumn{7}{c}{ Type of malignant tumour } \\
\cline { 2 - 8 } & $\begin{array}{c}\text { Trachea, } \\
\text { bronchi, } \\
\text { lungs }\end{array}$ & $\begin{array}{c}\text { Large } \\
\text { bowel }\end{array}$ & Breast & Cervix & Prostate & Ovary & Melanoma \\
\hline Dolnośląskie & 4 & 11 & 118 & 114 & 19 & 5 & 2 \\
\hline Kujawsko-Pomorskie & 4 & 8 & 27 & 38 & 11 & 0 & 6 \\
\hline Lubelskie & 5 & 6 & 72 & 44 & 4 & 0 & 1 \\
\hline tódzkie & 5 & 12 & 85 & 59 & 13 & 1 & 1 \\
\hline Małopolskie & 12 & 20 & 95 & 85 & 30 & 5 & 6 \\
\hline Mazowieckie & 26 & 41 & 282 & 188 & 27 & 5 & 19 \\
\hline Opolskie & 9 & 13 & 41 & 56 & 12 & 0 & 3 \\
\hline Podkarpackie & 9 & 16 & 65 & 44 & 5 & 0 & 1 \\
\hline Podlaskie & 0 & 3 & 29 & 28 & 0 & 0 & 1 \\
\hline Pomorskie & 18 & 17 & 86 & 75 & 28 & 1 & 2 \\
\hline Śląskie & 18 & 27 & 97 & 67 & 31 & 5 & 12 \\
\hline Świętokrzyskie & 9 & 22 & 107 & 107 & 8 & 3 & 8 \\
\hline Warmińsko-Mazurskie & 2 & 14 & 39 & 39 & 6 & 0 & 1 \\
\hline Wielkopolskie & 25 & 49 & 403 & 232 & 53 & 5 & 6 \\
\hline Zachodniopomorskie & 10 & 24 & 167 & 108 & 20 & 0 & 4 \\
\hline Lubuskie & 3 & 5 & 48 & 64 & 7 & 2 & 2 \\
\hline Total & 288 & 1761 & 1348 & 274 & 32 & 75 \\
\hline
\end{tabular}

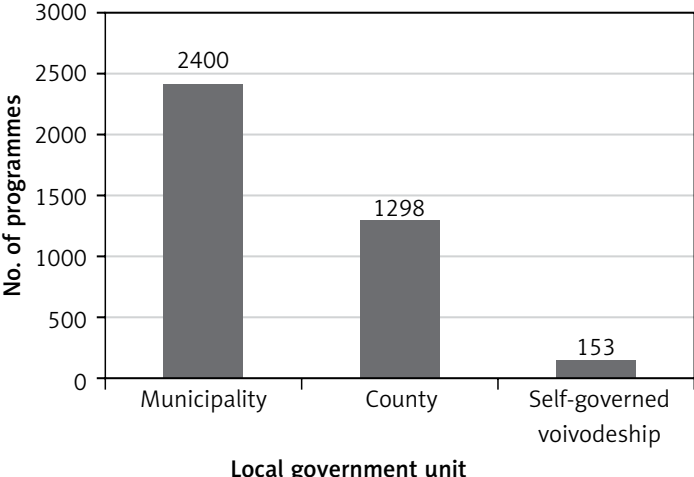

Figure 3. Frequency distribution - the number of programmes implemented in 2009-2014 by particular local government units
2010-2012 was higher than in 2009. In 20132014 the number of diagnostic programmes reached the level reported in 2009 (Table III). The relations between the type of programme (preventive programme, diagnostic programme, therapeutic programme, preventive, diagnostic and therapeutic programme) and the local government unit (municipality, county, voivodeship) were analysed (Table IV).

It was found that the most preventive and diagnostic programmes are held by municipalities, while counties implement fewer programmes, followed by voivodeships. The most therapeutic programmes are held by municipalities and counties, while the fewest programmes are im-

Table II. Frequency distribution - programmes implemented in particular years by particular local government units with $\chi^{2}$ test values for one sample

\begin{tabular}{|lccccccccc|}
\hline Local government unit & \multicolumn{9}{c}{ Year } \\
\cline { 2 - 11 } & 2009 & 2010 & 2011 & 2012 & 2013 & 2014 & $\chi^{2}$ & df & $P$-value \\
\hline Municipality & 314 & 414 & 378 & 445 & 420 & 429 & $28.33^{* \star \star}$ & 5 & 0.001 \\
\hline County & 260 & 298 & 213 & 168 & 177 & 182 & $63.09^{* \star \star}$ & 5 & 0.001 \\
\hline Self-governed voivodeship & 30 & 24 & 30 & 18 & 20 & 31 & 6.25 & 5 & 0.282 \\
\hline
\end{tabular}

$\chi^{2}$-test statistic, $d f$-number of degrees of freedom, $p$ - statistical significance, ${ }^{* * *} p<0.01$. 


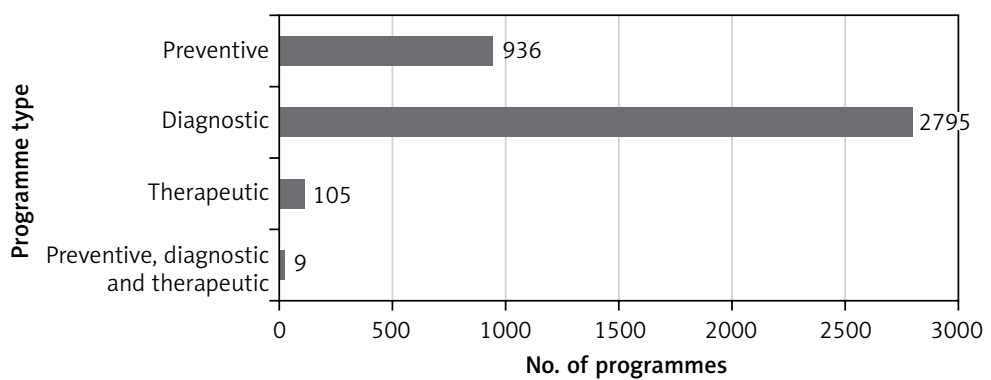

Figure 4. Frequency distribution - the number of preventive programmes, diagnostic programmes, therapeutic programmes, and preventive, diagnostic and therapeutic programmes implemented in 2009-2014

Table III. Frequency distribution - preventive programmes, diagnostic programmes and therapeutic programmes, and preventive, diagnostic and therapeutic programmes implemented in the successive years by particular local government units, along with $\chi^{2}$ test values for one sample

\begin{tabular}{|lccccccccc|}
\hline Programme type & \multicolumn{9}{c}{ Year } \\
\cline { 2 - 11 } & 2009 & 2010 & 2011 & 2012 & 2013 & 2014 & $\chi^{2}$ & $\mathrm{~d} f$ & $P$-value \\
\hline Preventive & 157 & 163 & 137 & 132 & 164 & 183 & $11.41^{*}$ & 5 & 0.044 \\
\hline Diagnostic & 438 & 548 & 458 & 475 & 441 & 435 & $19.83^{* *}$ & 5 & 0.001 \\
\hline Therapeutic & 8 & 20 & 20 & 22 & 12 & 23 & 10.49 & 5 & 0.063 \\
\hline $\begin{array}{l}\text { Preventive, diagnostic } \\
\text { and therapeutic }\end{array}$ & 1 & 1 & 1 & 2 & 2 & 2 & 1.00 & 5 & 0.963 \\
$\chi^{2}-$ test statistic, $d f$ - number of degrees of freedom, $p$ - statistical significance, ${ }^{*} p<0.05,{ }^{* *} p<0.01$. \\
\hline
\end{tabular}

Table IV. The number of preventive programmes, diagnostic programmes, therapeutic programmes, and preventive, diagnostic and therapeutic programmes implemented by municipalities, counties and voivodeships in 2009-2014

\begin{tabular}{|lcccccc|}
\hline Programme type & \multicolumn{3}{c}{ Local government unit } & \multicolumn{3}{c|}{ Test } \\
\cline { 2 - 8 } & Municipality & County & Voivodeship & $\mathbf{Q}$ & $\mathrm{d} f$ & $P$-value \\
\hline Preventive & 535 & 375 & 26 & $434.74^{\star * *}$ & 2 & $<0.001$ \\
\hline Diagnostic & 1814 & 870 & 112 & $1560.82^{* * *}$ & 2 & $<0.001$ \\
\hline Therapeutic & 48 & 45 & 12 & $22.80^{* * *}$ & 2 & $<0.001$ \\
\hline Preventive, diagnostic and therapeutic & 3 & 4 & 2 & 0.67 & 2 & 0.717 \\
\hline$Q-$ - Cochran's $Q$ test value, $d f-$ number of degrees of freedom, $p$ - statistical significance, ${ }^{* * *} p<0.001$. & &
\end{tabular}

plemented by voivodeships. The analysis also covered the number of preventive and diagnostic programmes implemented in particular voivodeships (Table V).

The most preventive programmes were implemented in Mazowieckie and Wielkopolskie voivodeships, the fewest in Świętokrzyskie and Podlaskie voivodeships. The most diagnostic programmes were implemented in Wielkopolskie and Mazowieckie voivodeships, the fewest in Kujawsko-Pomorskie, Warmińsko-Mazurskie and Podlaskie voivodeships.

The analysis also covered the diversity of programmes in terms of the population covered by a given programme. The number of programmes dedicated to children and teenagers or adults was determined, as well as the number of programmes targeting women and men (Figure 5). Based on Cochran's Q test it was found that there are sig- nificant differences between the numbers of programmes dedicated to adults, children, men and women, $\mathrm{Q}(3)=4355.15, p<0.001$.

The most programmes were addressed to women, fewer programmes were dedicated to adults, and programmes addressed to children and men were the least common.

The analysis also covered the total expenditure on the preventive programmes, diagnostic programmes, therapeutic programmes and preventive, diagnostic and therapeutic programmes in municipalities, counties and voivodeships (Table $\mathrm{VI}$ ).

A statistically significant interaction effect was found, $F(6.2002)=2.83, p<0.01, \eta^{2}=0.01$. The costs of particular types of programmes were determined by the local government unit that implemented the programme. Municipalities and counties spent the most on preventive programmes, 
Table V. The number of preventive and therapeutic programmes implemented in 2009-2014 according to voivodeships

\begin{tabular}{|c|c|c|}
\hline Voivodeship & $\begin{array}{c}\text { No. of } \\
\text { preventive } \\
\text { programmes }\end{array}$ & $\begin{array}{c}\text { No. of } \\
\text { diagnostic } \\
\text { programmes }\end{array}$ \\
\hline Dolnośląskie & 89 & 166 \\
\hline Kujawsko-Pomorskie & 35 & 50 \\
\hline Lubelskie & 37 & 92 \\
\hline Łódzkie & 46 & 123 \\
\hline Małopolskie & 57 & 176 \\
\hline Mazowieckie & 152 & 414 \\
\hline Opolskie & 64 & 67 \\
\hline Podkarpackie & 31 & 103 \\
\hline Podlaskie & 30 & 22 \\
\hline Pomorskie & 54 & 167 \\
\hline Śląskie & 57 & 172 \\
\hline Świętokrzyskie & 24 & 232 \\
\hline Warmińsko-Mazurskie & 41 & 50 \\
\hline Wielkopolskie & 94 & 638 \\
\hline Zachodniopomorskie & 61 & 259 \\
\hline Lubuskie & 64 & 64 \\
\hline Total & 936 & 2795 \\
\hline
\end{tabular}

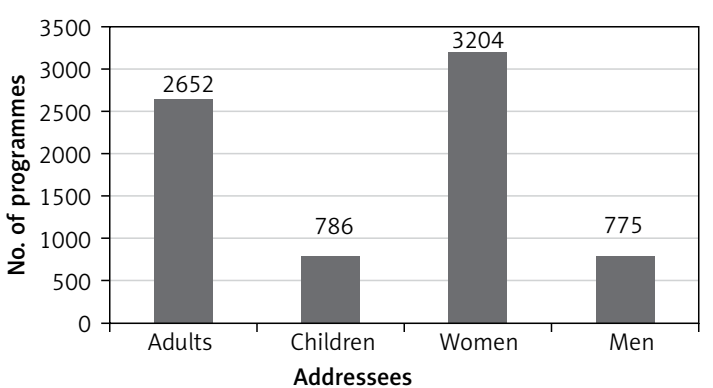

Figure 5. Frequency distribution - the number of programmes dedicated to adults, children, women and men implemented in 2009-2014

while voivodeships spent the most on diagnostic programmes.

The size of the population covered by a given programme depending on the year of implementation, implementing entity, type of programme and overall cost was analysed on the basis of regression analysis. The size of the population covered by a given programme was analysed as a variable in a regression analysis. The adopted predictors included the year of implementation, the implementing entity, the type of programme and total cost of the programme. A statistically significant model was obtained, $F(6.1908)=$ $16.69, p<0.001$. Table VII presents the regression coefficients along with statistical significance.

Statistically significant relations were found between the size of the population covered by

Table VI. Average overall costs (in PLN) of preventive programmes, diagnostic programmes, therapeutic programmes and preventive, diagnostic and therapeutic programmes implemented in municipalities, counties and voivodeships in 2009-2014

\begin{tabular}{|lccc|}
\hline Programme type & \multicolumn{3}{c|}{ Local government unit } \\
\cline { 2 - 4 } & Municipality & County & Voivodeship \\
\hline Preventive & 41880.00 & 91496.66 & 53301.48 \\
\hline Diagnostic & 18662.71 & 39395.87 & 240251.88 \\
\hline Therapeutic & 20153.61 & 70272.21 & 22863.27 \\
\hline Preventive, diagnostic and therapeutic & 26798.33 & 9758.00 & 44647.50 \\
\hline
\end{tabular}

Table VII. Regression coefficients and statistical significance

\begin{tabular}{|c|c|c|c|}
\hline Predictors & $\beta$ & $t$ & $P$-value \\
\hline Year of implementation & -0.06 & $-2.66^{\star \star}$ & 0.008 \\
\hline County executor & 0.01 & 0.56 & 0.575 \\
\hline Voivodeship executor & 0.21 & $9.09^{* \star \star}$ & $<0.001$ \\
\hline Preventive programme & 0.07 & $3.03^{* *}$ & 0.002 \\
\hline Therapeutic programme & 0.05 & $2.22^{*}$ & 0.026 \\
\hline Total cost & -0.03 & -1.18 & 0.237 \\
\hline
\end{tabular}


a programme and the year of implementation, the involvement of the voivodeship as the executor, and the preventive or therapeutic nature of a programme. No statistically significant relations were found between the size of the population covered by the programme and the involvement of a county as the executor, or the overall cost of the programme. The later the year of implementation of a programme, the smaller was the size of the population that the programme covered. Voivodeship programmes reached larger populations compared to municipalities. Pre- ventive and therapeutic programmes covered a larger number of people than diagnostic programmes.

The analysis also covered the effects of the programmes on the incidence and mortality due to malignant tumours (Tables VIII-X).

A statistically significant positive correlation was found between the standardized mortality ratio among women and the number of diagnostic programmes (Table XI).

A statistically significant positive correlation was found between standardized incidence ratio

Table VIII. The number of programmes implemented in 2009 and 2013

\begin{tabular}{|lccccc|}
\hline Year & Programme type & M & SD & Min. & Max. \\
\hline 2009 & No. of preventive programmes & 9.56 & 6.53 & 0 & 21 \\
\cline { 2 - 6 } & No. of diagnostic programmes & 27.38 & 21.46 & 4 & 81 \\
\hline 2013 & No. of therapeutic programmes & 0.44 & 1.03 & 0 & 4 \\
\cline { 2 - 6 } & No. of preventive programmes & 10.25 & 7.96 & 2 & 33 \\
\cline { 2 - 6 } & No. of diagnostic programmes & 27.56 & 28.38 & 3 & 119 \\
\hline
\end{tabular}

$M$ - mean value, SD - standard deviation, min. - minimum value, max. - maximum value.

Table IX. Standardized mortality ratios and standardized incidence ratios in 2009 and 2013

\begin{tabular}{|c|c|c|c|c|c|}
\hline Year & Ratio & M & SD & Min. & Max. \\
\hline \multirow[t]{4}{*}{2009} & Standardized incidence ratio men & 255.11 & 30.35 & 202.50 & 314.30 \\
\hline & Standardized incidence ratio women & 204.89 & 17.60 & 176.20 & 232.80 \\
\hline & Standardized mortality ratio men & 186.90 & 12.65 & 169.30 & 213.50 \\
\hline & Standardized mortality ratio women & 100.40 & 11.67 & 83.70 & 122.60 \\
\hline \multirow[t]{4}{*}{2013} & Standardized incidence ratio men & 266.77 & 27.81 & 205.10 & 309.90 \\
\hline & Standardized incidence ratio women & 217.04 & 21.45 & 180.60 & 266.10 \\
\hline & Standardized mortality ratio men & 168.37 & 12.08 & 143.80 & 194.30 \\
\hline & Standardized mortality ratio women & 95.96 & 8.88 & 77.90 & 106.60 \\
\hline
\end{tabular}

$M$ - mean value, SD - standard deviation, min. - minimum value, max. - maximum value.

Table X. Spearman's $\rho$ correlation coefficients between the number of preventive, diagnostic and therapeutic programmes implemented in voivodeships and the standardized incidence coefficients among women and men in 2009

\begin{tabular}{|c|c|c|c|c|}
\hline \multirow[t]{2}{*}{ Ratio } & & \multicolumn{3}{|c|}{ No. of programmes } \\
\hline & & Preventive & Diagnostic & Therapeutic \\
\hline \multirow[t]{2}{*}{ Standardized incidence ratio men } & $\rho$ & -0.303 & 0.158 & -0.138 \\
\hline & $p$ & 0.127 & 0.280 & 0.305 \\
\hline \multirow[t]{2}{*}{ Standardized incidence ratio women } & $\rho$ & -0.066 & 0.282 & -0.153 \\
\hline & $p$ & 0.404 & 0.145 & 0.286 \\
\hline \multirow[t]{2}{*}{ Standardized mortality ratio men } & $\rho$ & -0.053 & -0.012 & -0.054 \\
\hline & $p$ & 0.422 & 0.483 & 0.421 \\
\hline \multirow[t]{2}{*}{ Standardized mortality ratio women } & $\rho$ & 0.095 & $0.443^{*}$ & 0.186 \\
\hline & $p$ & 0.364 & 0.043 & 0.245 \\
\hline
\end{tabular}

$\rho$ - Spearman's $\rho$ correlation coefficient, $p$ - one-way statistical significance, ${ }^{*} p<0.05$, SIR - standardized incidence ratio, SMR standardized mortality ratio. 
Table XI. Spearman's $\rho$ correlation coefficients between the number of preventive, diagnostic and therapeutic programmes implemented in voivodeships and the standardized incidence coefficients among women and men in 2013

\begin{tabular}{|lcccc|}
\hline Ratio & \multicolumn{4}{c}{ No. of programmes } \\
\cline { 2 - 5 } & & Preventive & Diagnostic & Therapeutic \\
\hline SIR & $\rho$ & -0.368 & -0.065 & -0.276 \\
\cline { 2 - 5 } men & $p$ & 0.080 & 0.406 & 0.151 \\
\hline SIR & $\rho$ & -0.055 & $0.428^{*}$ & 0.155 \\
women & $p$ & 0.419 & 0.049 & 0.283 \\
\hline SMR & $\rho$ & 0.035 & -0.009 & 0.145 \\
men & $p$ & 0.449 & 0.487 & 0.296 \\
\hline $\begin{array}{l}\text { SMR } \\
\text { women }\end{array}$ & $\rho$ & 0.154 & 0.277 & 0.268 \\
\cline { 2 - 5 } & $p$ & 0.285 & 0.149 & 0.158 \\
\hline
\end{tabular}

$\rho$ - Spearman's $\rho$ correlation coefficient, $p$ - one-way statistical significance, ${ }^{*} p<0.05, S I R$ - standardized incidence ratio, SMR standardized mortality ratio.

among women and the number of diagnostic programmes.

\section{Discussion}

In 2009-2014, local government units completed in all 3,850 cancer programmes. Since 2011, the number of cancer programmes held by local governments has remained at a steady level. In the context of the significance of the health issue concerned, some doubts are raised by the lack of increased activity of local government units in terms of the number of implemented programmes, and the size of population covered by a given programme that is decreasing year by year.

The most programmes, including preventive programmes, were implemented by municipalities. However, each year, oncological programmes of the health policy were implemented by fewer than $18 \%$ of municipalities in Poland. Significantly greater involvement in the implementation of programmes of the health policy is observed among counties. In 2010 , more than $78 \%$ of counties implemented oncological programmes of the health policy. In the studied period, the fewest (i.e. more than 44\%) counties implemented the programmes in 2012. The largest amount of funds for the implementation of preventive programmes was spent by counties and the smallest was spent by municipalities. Counties, allocating most of the funds for preventive programmes, undertook the implementation of public tasks, determined by the provisions of law, which include the promotion and protection of health [14]. In the context of the potential effects of preventive programmes on the improvement of population incidence and mortality ratios associated with cancer [15-17], one must view the statistically significant increase in the number of preventive programmes in the following years as positive.

In 2009-2014, local government units implemented nearly three times more programmes of a diagnostic nature than of a preventive nature. In all, the amount of funds allocated for diagnostic and therapeutic programmes was twice as high $(411,599.55 \mathrm{PLN})$ as the amount spent on preventive programmes $(186,678.14)$. The amount is not objectionable, as a wide range of actions might be financed under a given health programme $[18,19]$. However, it might be symptomatic of deficits in the Polish healthcare system, which consist in imposing the obligation of financing certain health services on health policy programmes of a diagnostic and a therapeutic nature.

The most preventive programmes were implemented in Mazowieckie and Wielkopolskie voivodeships, the fewest in Świętokrzyskie and Podlaskie voivodeships. The most diagnostic programmes were completed in Wielkopolskie and Mazowieckie voivodeships, the fewest in Kujawsko-Pomorskie, Warmińsko-Mazurskie and Podlaskie voivodeships. In 2009 the highest values of standardised mortality ratios among men with malignant tumours were identified in Kujawsko-Pomorskie (213.5/100,000), Warmińsko-Mazurskie $(200.3 / 100,000)$ and Lubuskie $(197.2 / 100,000)$ voivodeships. The lowest ratios were identified in Podkarpackie $(169.3 / 100,000)$, Mazowieckie and Małopolskie (over 170/100,000) voivodeships. The standardized mortality ratios among women were found to be the highest in Kujawsko-Pomorskie (122.6/100,000), Pomorskie and Wielkopolskie (over 110/100,000) voivodeships. The lowest ratios were identified in Lubelskie (83.7/100,000), Podkarpackie $(84.9 / 100,000)$ and Podlaskie $(85.1 / 100,000)$ voivodeships. Assuming that the reduction of mortality among cancer patients requires implementation of initiatives in the area of health promotion and prevention as well as diagnosis and treatment of cancer [20], it should be stated that in Wielkopolskie Voivodeship, the health needs of the residents were assessed most accurately. A similar conclusion applies to local government units in Zachodniopomorskie Voivodeship, where the standardized mortality ratio in 2009 among men (191.6/100,000) and women $(106.9 / 100,000)$ was relatively high. In Kujawsko-Pomorskie and Warmińsko-Mazurskie voivodeships the number of completed programmes was insignificant despite the high standardized mortality ratios among women and men. In these voivodeships the health needs of citizens have not been properly addressed.

The number of health policy programmes aimed at diagnosis was analysed in terms of the increase in the detection rate of malignant tumours. 
In 2009, the largest number of patients diagnosed with malignant tumours came from the Pomorskie and the Dolnośląskie voivodeships (over 400 cases per 100,000 ), followed by patients from Łódzkie and Świętokrzyskie (over 380/100,000), and those from Wielkopolskie, Kujawsko-Pomorskie and Śląskie (over 370/100,000). The lowest incidence of malignant tumours was identified among the inhabitants of the Podlaskie and the Zachodniopomorskie voivodeships - fewer than $300 / 100,000$ [21]. In terms of the detection of malignant tumours, the situation was similar in 2010 [22] and in 2012 [4]. Despite the high detection rate of malignant tumours, the most frequent programmes implemented by local government units in Wielkopolskie Voivodeship in 2009-2014 were diagnostic programmes (638). The case was similar for Świętokrzyskie and Pomorskie voivodeships, which completed a relatively large number of diagnostic programmes (232 and 167 respectively). The activity of the local government units of Mazowieckie and Zachodniopomorskie also deserves a positive evaluation. In Zachodniopomorskie Voivodeship the number of newly detected tumours grew quickly in 2012 (increase of $20 \%$ compared to the previous year) [4]. One should expect that in the years to come, due to the implementation of diagnostic programmes, the detection rate recorded for the voivodeships should grow. Podlaskie Voivodeship ranks among the voivodeships with the lowest detection of malignant tumours. Therefore, the insufficient activity of local government units in this voivodeship in terms of implementation of diagnostic programmes must be viewed in a negative light. The voivodeship completed the smallest number of diagnostic programmes in 2009-2014.

The activity of local government units in terms of implementation of health policy programmes concerning the most common types of tumours in the Polish population has also been analysed. The most registered cases of malignant tumours in 2009 in women concerned patients with breast cancer $(22.8 \%)$, colorectal cancer $(10.0 \%)$, lung cancer $(8.5 \%)$, cancer of the corpus uteri $(7.3 \%)$, ovarian cancer $(5.0 \%)$ and cervical cancer $(4.5 \%)$ [5]. A similar situation in the case of women was observed in 2013 [6]. For men, the most frequently diagnosed malignant tumours in 2009 were lung cancer $(21.4 \%)$, prostate cancer $(13.3 \%)$, colorectal cancer (12.1\%), bladder cancer $(6.8 \%)$ and stomach cancer (5.0\%) [5]. Also, in 2013, these cancers were most frequently registered in men [6]. Local government units implemented health policy programmes that concerned the most common malignant tumours in the Polish population. As part of the National Programme for Fighting Cancer, there are programmes such as: "Population programme of prevention and early diagno- sis of cervical cancer", "Population programme of early diagnosis of breast cancer" and "Programme of screening tests for early diagnosis of colorectal cancer". The programmes concerning breast cancer implemented by local government units accounted for $46 \%$ of the overall number of programmes, cervical cancer programmes accounted for $35 \%$ and colorectal cancer programmes accounted for $7.48 \%$ of the overall number. In all, over $88 \%$ of programmes implemented by local government units concerned malignant tumours covered by initiatives under the National Programme for Fighting Cancer. Programmes implemented by local government units constituted a repetition of the actions undertaken at a national level.

The assessment also covered the number of cancer programmes dedicated to adults, also in terms of the number of programmes dedicated to women and men, children and teenagers. In 2010 again, starting from 2007, the incidence of cancer among women was greater than among men [7]. In a population of young adults (20-44), the incidence ratios for women are almost twice as high as the ratios measured for men $(87 / 100,000$ vs. 49/100,000), and the difference has been increasing since the early 1980s. The increase in the incidence of the disease in men and women, observed since the early 1990s in the eldest age group (above 65 years old), temporarily decreased in the last decade of the $20^{\text {th }}$ century for men, while it continues to grow in women [6]. Malignant tumours are the main cause of premature death in people aged below 65. The tendency is clear especially in the population of women. For several years now, cancer in patients aged below 65 has been the most frequent cause of death; it accounts for $33 \%$ of deaths in the population of young women and $49 \%$ of deaths in the population of middle-aged women [6]. In 2009-2014, local government units addressed most of their cancer programmes to women (486). In light of the above data, it seems intentional and well-founded.

The fewest cancer programmes were addressed to children (84), and in light of the data on cancer in children and teenagers, it seems justified. Cancers in children and teenagers (0-19) are a relatively rare cause of death (in 2009, 5.2\% of deaths among boys, and $5.5 \%$ of deaths among girls [5]; in 2013, $6.0 \%$ of deaths among boys and $7.6 \%$ of deaths among girls [6]). The number of deaths due to cancer has been decreasing for around 40 years, with a steady increase in the incidence of the disease, which demonstrates the progress made in the area of childhood cancer treatment.

In European Union member states, it is believed that the efficiency of treatment for malignant tumours is an important indicator of progress made by civilisation. Provisions on fighting 
cancer have been included in the Maastricht Treaty, and funds for implementation of the Europe Against Cancer programme are allocated from the budget of member states. In 1986, a group of EU experts drew up the European Code Against Cancer, whose final version was accepted at the end of 1994. The main objectives of actions held in EU member states are primary prevention, preventive mass tests, specifically screening tests, access to early diagnosis methods, dissemination of evidence-based treatment methods and access to palliative and end-of-life care [20]. The accomplishment of these objectives requires cooperation of international organisations, central and local authorities, non-governmental organisations, foundations, and scientific societies [23]. The results of programmes implemented in EU member states point to the special role of screening tests in the improvement of detection rates and the decrease in the number of deaths due to malignant tumours [24-27]. The above approach is also confirmed by Polish data [28]. One of the significant elements of therapy management is the adaptation of healthcare institutions to treatment of specific types of tumours [29]. Care coordination is an organisational element which is supposed to improve the efficiency and effectiveness of cancer care [30]. The relationship between the efficiency of cancer treatment and the consequences and time of the implementation of national programmes for early diagnosis of cancer is stressed [31-33]. It is equally essential to monitor the quality and correct the practices and tests aimed at the factors that determine the success of treatment [34].

In conclusion, a very high degree of differentiation of involvement of particular voivodeships in fighting cancer regarding the number of implemented health programmes was observed. Various degrees of involvement of particular types of local government units in the implementation of health programmes in the field of cancer were observed. Taking into account the standardised coefficient of mortality in Kujawsko-Pomorskie Voivodeship and Warmińsko-Mazurskie Voivodeship, collectivity and incoherence of actions, which do not take into consideration the actual health needs in the field of cancer, are noticed. The repeatability of actions undertaken at a local and a national lev$\mathrm{el}$ in the field of the most frequent malignancies occurring in Poland may indicate limited effectiveness of the policy of combating cancer. Due to an increasing number of diseases and high mortality resulting from malignancies in Poland, it is necessary to implement more programmes within the health policy and increase the population covered by the programmes. Actions undertaken by local governments should take into account the region- al specificity of the health situation regarding malignancies and be consistent with the guidelines arising from documents determining the national policy for fighting malignancies.

\section{Conflict of interest}

The authors declare no conflict of interest.

\section{References}

1. Krajowy Rejestr Nowotworów, http://onkologia.org.pl/, access 12 March 2016.

2. Uchwała Rady Ministrów Nr 208 z 3 listopada 2015 r. w sprawie ustanowienia programu wieloletniego na lata 2016-2024 pod nazwą „Narodowy Program Zwalczania Chorób Nowotworowych", M.P. z 2015, poz. 1165 [Polish].

3. World Cancer Report 2008, http://www.iarc.fr/en/publications/pdfs-online/wcr/2008/wcr_2008.pdf, [Polish] access 12 March 2016.

4. Zdrowie i ochrona zdrowia w 2014 r., Główny Urząd Statystyczny, Warszawa 2015, http://stat.gov.pl/obszarytematyczne/zdrowie/zdrowie/zdrowie-i-ochrona-zdrowia-w-2014-r-,1,5.html [Polish], access 12 March 2016.

5. Didkowska J, Wojciechowska U, Zatoński W. Nowotwory złośliwe w Polsce w 2009 roku. Warszawa 2011, http://onkologia.org.pl/wp-content/uploads/Nowotwory_2009.pdf [Polish], access 12 March 2016.

6. Didkowska J, Wojciechowska U. Nowotwory złośliwe w Polsce w 2013 roku. Warsaw 2015, http://onkologia. org.pl/wp-content/uploads/BIUL2013.pdf [Polish], access 12 March 2016.

7. Didkowska J, Wojciechowska U, Zatoński W. Nowotwory złośliwe w Polsce w 2010 roku. Warsaw 2012, http://onkologia.org.pl/wp-content/uploads/Nowotwory_2010.pdf [Polish], access 12 March 2016.

8. Didkowska J, Wojciechowska U, Zatoński W. Nowotwory złośliwe w Polsce w 2011 roku, Warszawa 2013, http:// onkologia.org.pl/wp-content/uploads/COI_Nowotwory2013_web.pdf [Polish], access 12 March 2016.

9. Didkowska J, Wojciechowska U, Zatoński W. Nowotwory złośliwe w Polsce w 2012 roku, Warsaw 2014, http:// onkologia.org.pl/wp-content/uploads/Biul2012net.pdf [Polish], access 12 March 2016.

10. Bielska-Lasota M, Car J, Rzepczak-Zacharek E. Obciążenie nowotworami złośliwymi w Polsce na tle krajów Unii Europejskiej. In: Sytuacja zdrowotna ludności Polski i jej uwarunkowania. Wojtyniak B, Goryński P, Moskalewicz B (eds) [Polish]. Narodowy Instytut Zdrowia Publicznego - Państwowy Zakład Higieny, Warszawa 2012; 153-69.

11. Strategia Walki z Rakiem w Polsce 2015-2024. http:// walkazrakiem.pl/sites/default/files/library/files/strategia_walki_z_rakiem_w_polsce_2015_2024.pdf [Polish], access 12 March 2016.

12. Biała Księga. Zwalczanie raka jelita grubego i raka piersi w Polsce na tle wybranych krajów europejskich. Analiza zasobów systemu opieki onkologicznej i czynników warunkujących sukces [Polish]. Ośrodek Analiz Uniwersyteckich, Warsaw, Krakow 2011.

13. Ustawa z 1 lipca 2005 r. o ustanowieniu programu wieloletniego "Narodowy program zwalczania chorób nowotworowych” (Dz.U. Nr 143, poz. 1200 z późn. zm.) [Polish].

14. Ustawa z 5 czerwca 1998 r. o samorządzie powiatowym (Dz.U. z 2015 r., poz. 1445 z późn. zm.) [Polish]. 
15. Badura B, What is and What Determines Health. In: Scientific Foundations for Public Health Policy in Europe. Laaser U, de Leeuw E, Stock C (eds.). Juventa Verlag, Munchen 1995.

16. WHO Europe, The European health report 2005: Public health action for healthier children and populations.

17. WHO, Global Strategy on Diet, Physical Activity and Health, Geneva, 2004 (http:// www.who.int/gb/ebwha/ pdf_files/WHA57/ A57_R17-en.pdf, access 9 March 2016.

18. Augustynowicz A, Budziszewska-Makulska A. Nowe zasady przekazywania środków publicznych na realizację programów zdrowotnych w świetle przepisów ustawy o działalności leczniczej [Polish]. Prawo i Medycyna 2012; 3-4: 114-36.

19. Pietraszewska-Macheta A, Kowalska-Mańkowska I, Sidorko A, Urban K. Ustawa o świadczeniach opieki zdrowotnej finansowanych ze środków publicznych. Komentarz [Polish]. Wolters Kluwer, Warsaw 2015.

20. Zachorowalność i umieralność na nowotwory a sytuacja demograficzna Polski [Polish]. Rządowa Rada Ludnościowa, Warsaw 2014.

21. Zdrowie i ochrona zdrowia w 2011 r., Warszawa: Główny Urząd Statystyczny; 2012, http://stat.gov.pl/cps/rde/ xbcr/gus/zo_zdrowie_i_ochrona_zdrowia_w_2011.pdf [Polish], access 22 March 2016.

22. Zdrowie i ochrona zdrowia w 2012 r., Warszawa: Główny Urząd Statystyczny; 2013, http://stat.gov. pl/obszary-tematyczne/zdrowie/zdrowie/zdrowie-iochrona-zdrowia-w-2012-r-,1,3.html [Polish], access 12 March 2016.

23. Mellstedt $\mathrm{H}$. Cancer initiatives in developing countries. Ann Oncol 2006; 17 (Suppl. 8): 24-31.

24. Puliti D, Miccines G, Manneschi G, et al. Does an organised screening programme reduce the inequalities in breast cancer survival? Ann Oncol 2012; 23: 319-23.

25. Pollan M, Michelena MJ, Ardanaz E, et al.; the Breast Cancer Working Group, Breast cancer incidence in Spain before, during and after the implementation of screening programmes. Ann Oncol 2010; 21 (Suppl. 3): 97-102.

26. Norum J. Breast cancer screening by mammography in Norway. Is it cost-effective? Ann Oncol 1999; 10: $197-$ 203.

27. Sharma D, Newman GT, Aronow SW. Lung cancer screening: history, current perspectives, and future directions. Arch Med Sci 2015; 11: 1033-43.

28. Klimczak A, Kempińska-Mirosławska B, Mik M, Dziki t Dziki A. Colorectal cancer mortality in Poland - analysis of regional variation. Arch Med Sci 2014; 10: 63-7.

29. Harling H, Bülow S, Møller LN, Jørgensen T. Hospital volume and outcome of rectal cancer surgery in Denmark 1994-1999. Colorectal Dis 2005; 7: 90-5.

30. Walsh J, Young JM, Harrison JD, et al. What is important in cancer care coordination? A qualitative investigation. Eur J Cancer Care 2011; 20: 220-7.

31. Tryggvadóttir L, Gislum M, Bray F, et al. Trends in the survival of patients diagnosed with breast cancer in the Nordic countries 1964-2003 followed up to the end of 2006. Acta Oncol 2010; 49: 624-31.

32. Klint Å, Tryggvadóttir L, Bray F, et al. Trends in the survival of patients diagnosed with cancer in female genital organs in the Nordic countries 1964-2003 followed up to the end of 2006. Acta Oncol 2010; 49: 632-43.

33. Hakama M, Hoff G, Kronborg O, Påhlman L. Screening for colorectal cancer. Acta Oncol 2005; 44: 425-39.

34. Wibe A, Carlsen E, Dahl O, et al.; The Norwegian Rectal Cancer Group. Nationwide quality assurance of rectal cancer treatment. Colorectal Dis 2006; 8: 224-9. 